\title{
CORRESPONDENCE
}

\section{Huxley on Nature}

SIR - You quote the president of the Royal Society (Nature 4 June, p.373), speaking at the centenary celebrations for the British Museum (Natural History), as criticizing Nature for having "printed more than 30 letters. . relating to cladistics, which would have been unintelligible to 99 per cent of the readership",

But, sir, would that not apply equally to many of the other topics dealt with, and rightly dealt with, in the pages of your esteemed journal? Elitist it may be, but it is to be hoped that you will continue to give space to technical scientific matters, especially when these are a subject of controversy, commensurate with their interest and importance, even though this may be apparent to no more than a small minority of your readership.

C. B. GOOdharT

University Museum of Zoology,

Cambridge, UK

\section{Cabal of referees}

$\mathrm{S}_{\mathrm{I}}-$ The article in Nature referring to the policing of the publication of scientific literature (9 April, p.433) raises a major issue.

We suggest that the main reason for the problems now surfacing and referred to in this article is the existence of a refereeing system which has turned into a cabal and like all secret societies is plagued by corruption.

This problem has already been raised by an assistant editor of the journal Nuclear Physics, who felt that the present anonymous system of peer review results in injustices to authors and is inappropriate to the spirit of science (P. Robertson New Scientist 71, 410; 1976.)

Quite clearly, the reputation of this system is now at stake. Could it be that the scientific community at large is not yet mature enough to handle the problems that may arise from a more open system?

\section{M.A. GII.LMAN}

F.J. LICHTIGFELD

Medical School,

University of the Witwatersrand,

Johannesburg, South Africa

\section{Book for safety}

SiR - In an editorial on nuclear politics (Nature 4 June, p.368) you suggest that governments should be responsible for safety and responsive to the views of the electors. This is to recognize the democratic imperative, but you might have added the need to inform the electorate about safety matters. With these, as with all difficulties, the strength of a democracy depends on the sense of its citizens.

One of our functions at the National Radiological Protection Board is indeed to provide information on radiation safety, and we do so in several ways. Because of public anxiety about nuclear issues, we discuss thern impartially in a new general publication Living with Radiation (Her Majesty's Stationery Office, London, 1981; 50 pence) which we hope will promote cool debate and calm judgement.

M.C. O'RIORDAN

National Radiological Protection Board, Chilton, Didcot, UK

\section{Wheel re-invented}

SIR - The recent report by K.S. Jayaraman (Nature 28 May, p.277) describing the "gunny-bag air conditioner" developed by the Central Building Research Institute in India, provides an excellent example of the redevelopment of wheels at government expense. The process of passive cooling by roof-surface evaporation is as Jayaraman says suitable not only for India and other developing countries in the tropics but for large areas of American suburbia where for many years the advent of summer has been marked by the temporary placement of lawn sprinklers on the ridge of the roof.

\section{J.P. BENTLEY}

University of Oregon Health Sciences Center, Portland, Oregon, USA

\section{Doomed subspecies}

SIR - How would a sociobiologist explain the existence of anti-sociobiologists?

Undoubtedly, most people in the world would claim to be basically generous, caring, and unselfish individuals. Sociobiology, with its fundamental emphasis upon the selfishness of human nature, thus represents a minority view.

But even if the majority view of human nature is untrue, being the result of genes which have been selected for such

"deception", might anti-sociobiologists nevertheless receive greater fitness benefits from this majority?

Might one expect to see the demise of sociobiology over evolutionary time due to the decreased fitness of sociobiologists relative to anti-sociobiologists?

Syracuse, New York, USA

\section{Divergent usage}

SIR - I would like to note a common and unfortunate misuse of terms. In his Origin of the Species, Darwin noted that similarities among organisms could arise from convergence because separate lines of descent independently acquired a function, or by divergence from a common ancestor. I do not know who coined the words, but Darwin used analogy to describe the former and homology to describe the latter. That useful distinction has served biologists well for over a hundred years.

The clarity of these concepts is now being widely abandoned as illustrated by your associate editor who presents the conclusion "that the homology is due to divergent rather than convergent evolution" ". She thus presents us with a choice between a tautology (homology due to divergence) and a contradiction in terms (homology due to convergence).

One should use similarity for the meaning that homology must have in the above quote for reasons far more important than a personal preference for Latin over Greekderived words or preserving a time-honoured usage. Similarity is an observation while homology is an inference about its origins. To use homology with both meanings is to confuse the data with the hypothesis. And how much simpler it is to conclude, "The similarity is homologous rather than analogous".

WAlter M. Fitch RONALD L. NIECE

Department of Physiological Chemistry, University of Wisconsin-Madison,

Madison, Wisconsin, USA

1. Robertson, M. Nature 290, 187 (1981).

\section{Credit due to Nabi}

SIR - It has recently been suggested in the columns of Nature that I am the mysterious Isidore Nabi (Nature 23 April, p.623). I would like to do what I can to clarify the situation. Let me state categorically that any assertion that Isidore $\mathrm{Nabi}$ is none other than R. C. Lewontin is incorrect. Let me offer a few corroborative details.

(1) According to his biography in American Men and Women of Science, Dr Nabi is 71 years old, received his bachelor's degree from Cochabamba University, and, among other things, has lectured and carried out research at the University of Venezuela for five years. I, on the other hand, am 52 , have never even heard of Cochabamba University, and have never been south of Mexico City.

(2) Dr Nabi is the editor of the journal Evolutionary Theory on whose editorial board I also appear by name, and I also find him listed as a member of the Evolution Society of which I once had the honour of being president. Why would Professor Van Valen, managing editor of Evolutionary Theory, list me on the editorial board if I were also, under a different name, editor of that worthy journal? And what in the world would I do with an extra copy of American

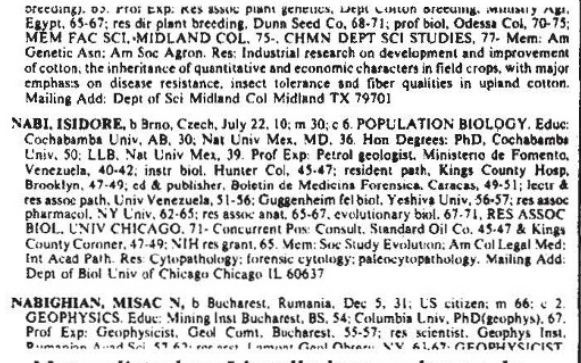

Naturalist when I hardly know what to do with my own?

(3) Isidore Nabi is the author of several important works which, I am sorry to say, are not at all of my creation. I refer in particular to his brilliant "On the Properties of Motion" which is as yet unpublished but widely circulated and known, and his seminal work "An Evolutionary Interpretation of the English Sonnet".

I have recently received a letter from Professor Van Valen saying that he has been identified as the Isidore Nabi who wrote the letter to Nature, an assertion which he denies. Thus, confusion multiplies. I hope that this letter has thrown some light on the situation.

RICHARD C. LEWONTIN

Museum of Comparative Zoology,

Harvard University, Massachusetts, USA 